\title{
Avicennan Troubles: The Mysteries of the Heptagonal House and of the Phoenix
}

Thérèse-Anne Druart The Catholic University of America druart@cua.edu

\begin{abstract}
In the Metaphysics of the Shifâ, Avicenna distinguishes three ways in which universals are said. The second sense is puzzling since Avicenna explains that universals are said of what it is permissible to say of many, even if it is not a condition that these many should exist in actuality, and he illustrates this kind of universals with the "heptagonal house". In its nature this universal can be said of many, but it does not follow necessarily that these many must exist-not even one of them. This second case deals with a less common type of universal, since such universals may have either only one instantiation or even none at all. The example of the heptagonal house is not traditional, as Greek sources, such as Porphyry and Simplicius, use the phoenix instead. In this paper Thérèse-Anne Druart explores in depth the use of this particular illustration, namely, the "heptagonal house".

Key words: Avicenna, universals, metaphysics, heptagonal house, phoenix.
\end{abstract}

Recibido: O6-OI-20I I. Aceptado: O3-IO-2OI I.

Tópicos 42 (2OI2), 5I-73 


\section{Resumen}

En la Metafísica de la Shifâ Avicena distingue tres modos en que se predican los universales. El segundo sentido resulta desconcertante puesto que Avicena explica que los universales se dicen de aquello que puede predicarse de muchos, incluso si no es necesario que éstos existan en acto y, para ilustrar esta clase de universales, recurre al ejemplo de "la casa heptagonal". En su naturaleza, esta clase de universal puede predicarse de muchos pero de ahí no se sigue que estos muchos existan, ni siquiera uno de ellos. Este segundo caso se refiere a un universal poco común, pues estos universales tienen, ya sea una única instanciación, o ninguna en lo absoluto. El ejemplo de la casa heptagonal no es tradicional, dado que fuentes griegas como Porfirio y Simplicio emplean el ejemplo del ave fénix. En este artículo Thérèse-Anne Druart explora a profundidad el particular ejemplo de la "casa heptagonal".

Palabras clave: Avicena, universales, metafisica, casa heptagonal, fénix.

Avicenna, as the Persian philosopher Ibn Sînâ (980-I037) is known in Latin, often presents his philosophy in such a dry style that at times one wonders what exactly he is talking about, particularly in the Metaphysics of his encyclopedic al-Shifâ', a text written in Arabic and translated into Latin in the Middle Ages. So the reader is pleasantly surprised to find in Book V, ch. I of this text examples of the three ways in which universals are said. First, universals are said of a meaning actually predicated of many, such as the human being. In this standard case the universal has several instantiations and the example is traditional. Second, universals are said of what it is permissible to say of many, even if it is not a condition that these many should exist in actuality, for example the heptagonal house. In its nature this universal can be said of many, but it does not follow necessarily that these many must exist — not even one of them. This second case deals with a less common type of universal, 
since such universals may have either only one instantiation or even none at all. The example of the heptagonal house is not traditional, as Greek sources, such as Porphyry and Simplicius, instead use the phoenix. The third case addresses another kind of less common universal, one whose meaning can be said of many but some external cause - and this can be proven - prevents such attribution to many. Thus, this universal has only one real instantiation, for example the sun and the earth, which both for the Greeks and for Avicenna are eternal. ${ }^{\mathrm{I}}$ This third kind and its illustration are traditional and attested in Greek sources.

My paper focuses on the second kind of universal, and in particular its illustration, the heptagonal house, which Avicenna substituted for the traditional phoenix, and for which some Latin readers of Avicenna, returning to the Greek sources and referring to this very passage, reinserted the phoenix and omitted the heptagonal house. Why did Avicenna substitute the heptagonal house for the phoenix and why did some of his Latin readers, such as Nicholas of Cornwall, return to the phoenix? ${ }^{2}$ The first part of my paper will explain why this substitution of the heptagonal house for the phoenix is puzzling and will reject some of the interpretations previously given. The second part will explain why in metaphysics or logic Avicenna could not use the phoenix or any other mythological bird or animal in order to illustrate this kind of universal and the third and last part, which is more speculative, will suggest why he substituted the heptagonal house for the phoenix in the Metaphysics of the Shifấ.

'For the Arabic, see Ibn Sînâ, Al-Shifâ', Al-Ilâhiyyât (I) (La métaphysique), ed. Anawati \& Zayed, I95, from now on referred as the Cairo ed. For the Cairo text, minus the apparatus criticus, and with an English translation, see Avicenna, The Metaphysics of The Healing, ed. Marmura, I48-49, nn. I-3. For the medieval Latin translation, see Avicenna Latinus, Liber de philosophia prima sive scientia divina, $V$-X, ed. S. Van Riet, 227-28. Consultation of the apparatus critici of both the Cairo edition and the critical edition of the Latin version as well as consultation of the corrections to the Cairo edition in Bertolacci (2006), 5I I, reveals that there is no alternative reading to the "heptagonal house."

${ }^{2}$ On Nicholas of Cornwall, see de Libera (I996), 234-38. On the three meanings of "universal" in Avicenna and the shift from the phoenix to the heptagonal house and back to the phoenix, see de Libera (I999), 509-I5. 


\section{The Problem and Some False Solutions}

The substitution of the heptagonal house for the phoenix has puzzled later disciples of Ibn Sînâ writing in Arabic and clearly some of his Latin readers since they dropped the heptagonal house and returned to the phoenix, as well as contemporary scholars. But before dealing with interpretations, it seems wise to look at other parallel texts in Ibn Sînâ, even if they were not translated into Latin. The Shifâ', which, as we said, introduces the heptagonal house, preceded all of them. It was followed by a revised, abbreviated form of the Shifâ' called the Najât and later on by a text in Persian, the Dânesh-Nâmeh or Philosophy for 'Alâ'-adDawla, also known in its French translation as The Book of Science. ${ }^{3}$ In the logic section of these two texts Ibn Sinâ avoids the problem of the heptagonal house and the phoenix by simply listing only two kinds of universals, the standard one with its example of the human being and the second, less common one, that of the universal with one eternal instantiation, such as the sun. ${ }^{4}$ The metaphysical section of these two texts focuses on the ontological status of universals, but does not list the kinds of universals nor does it define them.

Things become more interesting but still more confusing when we consider the logic section of the last of the parallel texts, the Ishârât also known both as Pointers and Reminders and as Admonitions and Remarks, the metaphysical part of which yields nothing useful. In its logic section, the first and third kinds are still those of universal with several instantiations and universal with only a single, eternal instantiation whose singleness derives from a cause external to the intelligible content of this universal, each kind provided with its traditional example, the human being, for the first, and the sun, for the third. The second kind speaks of universals common in potency and possibility and no longer gives the example of the heptagonal house but that of the sphere in which is inscribed the regular dodecahedron whose faces are pentagons rather

\footnotetext{
${ }^{3}$ For the chronology of Ibn Sînâ's main texts, see Gutas (I988), I 45.

${ }^{4}$ Ibn Sînâ, Najât, ed. Pazhuh, IO, and Avicenne, Le livre de science, I: Logique, Métaphysique, transl. Achena \& Massé, 68.
}

Tópicos 42 (2012) 
than heptagons. ${ }^{5}$ Now Ibn Sinâ has replaced the heptagonal house with a sphere containing one of the five regular solids that can be inscribed therein. The theorem dealing with the inscription of five regular solids in a sphere was already known at the time of Plato, since Plato, who was a solid geometry buff, used it in the Timaeus, but had some trouble with the construction of the dodecahedron. As Euclid's Elements were translated into Arabic, this theorem was well-known in Islamic lands. Whether one considers the heptagonal house or the sphere in which a regular dodecahedron is inscribed, it is clear that Ibn Sînâ is referring to some difficult geometric construction and to an artifact. Our original question of why Avicenna replaced the phoenix, which, if it were to exist, would be a natural kind, with a heptagonal house, seems to have become the following: why did he substitute for the phoenix, a fabulous animal, an artificial object whose geometric construction either had not yet been discovered or was difficult, which rendered instantiations either impossible or very rare?

Alain de Libera claims that some unspecified scholars assume that Avicenna rejected the phoenix because this was a mythical bird unknown to his culture and so replaced it with some other mythical "thing" more familiar to his readers, the heptagonal house. He rightly points out that this does not make much sense as in fact Ibn Sînâ in other unspecified texts refers to the phoenix, ${ }^{6}$ or more exactly a mythical bird of his own culture, the 'anqâ', at times also called in a more flowery manner 'anqâ' mughrib, meaning the marvelous 'anqâ'. He does so in the De interpretatione of the Shifâ, ${ }^{7}$ The Letter on the Disappearance of the Vain Intelligible Forms after Death, ${ }^{8}$ and his Refutation of Astrology, all texts

5Ibn Sînâ (I983), Al-Ishârât wa-t-tanbîhât, part I, ed. Donyâ, I49.

${ }^{6}$ de Libera (I999), 5I2

${ }^{7}$ Ibn Sînâ (I970), 77, 82-5, 89, I08-I I I.

${ }^{8}$ Arabic text and French translation in Avicenne (I987), " 'L'épître sur la disparition des formes intelligbles vaines après la mort' d'Avicenne," ed. Michot, I52-67. English translation Avicenna, "Avicenna's 'Letter on the Disappearance of the Vain Intelligible Forms after Death'," ed. J. Michot, 94-IO3. 
unknown to the Latins. ${ }^{9}$ The famous translator from Greek or Syriac into Arabic, Ishâq ibn Hunayn, had already used this 'anqâ' to translate the word "sphynx" in Aristotle's Physics at 208a29f ${ }^{\mathrm{IO}}$ and Avicenna's predecessor, the philosopher/logician al-Fârâbî (870-950) had added the 'anqâ' as an example of a fabulous animal parallel to that of the famous 'goat-stag' in his Long Commentary on Aristotle's De Interpretatione, I6a9-I9. II Ibn Sînâ follows suit in his own De interpretatione section of the Shifâ' in a passage in which he tortures the Arabic language into construing two different formulations of the sentence "the 'anqâ' is not endowed with eyesight," one that is true as it does not have existential import, and another that is not true as it has existential import, and, therefore, assumes the real existence of the 'anqâ'. ${ }^{\mathrm{I} 2}$

On the level of terminology for people working on translations from Arabic things get rather confusing as 'anqâ', the Arabic name of this fabulous bird, gets translated by some as "phoenix" (Black) ${ }^{\mathrm{I} 3}$, by others as "sphynx" (Zimmermann) ${ }^{\mathrm{I}}$, and by still others as "griffon" (Bäck). ${ }^{\mathrm{I}}$

But what is this famous 'anqâ'? Charles Pellat describes it as a fabulous bird similar to the phoenix. According to a hadith reported by alMas'ûdî (d. 957) and referring to pre-Islamic times, the 'anqâ' was created by God with all sorts of perfections but became a plague and was elim-

${ }^{9}$ Avicenne, Réfutation de l'astrologie, ed., translation, intro., and notes Michot, 2006.

${ }^{\text {Io }}$ See Zimmermann (I98I), I5, n. 4.

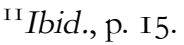

${ }^{12}$ Ibn Sînâ, De l'interprétation, ed. el-Khodeiri, 82 and a similar passage in Najât, ed. Pazhuh, 28. On relevant aspects of Avicenna's logic, see Bäck (I987), 35I-67, and particularly, 360, n. 34, for his translating 'anqâ' as griffon.

${ }^{13}$ Black (I997), 425-53.

I4Zimmermann (I98I), I5.

${ }^{15}$ In one text in Arabic, The Book of Definitions, definition 97, Avicenna alludes to this bird but in using its Persian name "qaqnus." See Kennedy-Day (2003), II 3 for the translation and I45-47 for a commentary. The same goes for the Physics of the Shifâ', IV, 3, ed. McGinnis, 4IO (reference kindly given to me by Jon McGinnis). In both case the "qaqnus" is simply an illustration for something white in color.

Tópicos 42 (2012) 
inated by some pre-Islamic prophet. ${ }^{\mathrm{I} 6}$ In this version of the legend it becomes an extinct species. "After Islam," writes Pellat, "the 'anqâ' was definitely assimilated with the simurgh, which plays some part in Iranian mythology."I7

In his Refutation of Astrology Ibn Sînâ dedicates one paragraph to explaining how human beings came to imagine or to believe in the 'anqâ' mughrib and so gives us some glimpses of which version of the legend he is thinking of. People would have liked to see far-away cities and kingdoms, as well as their inhabitants and marvels, but found travels painful and difficult, particularly if they did not own a she-camel, and so thought that flying would make things easy. They, therefore, imagined a flying human being, which they dubbed 'anqâ' mughrib. Afterwards they invented marvelous stories and tales and attributed them to learned people. Such tales about the 'anqa' are well known among the nations but "this thing [, i.e., the 'anqâ',] is impossible (muhâl) as one knows with a minimum of reflection." ${ }^{18}$ What that minimum of reflection is remains unexplained. We can now safely conclude that Avicenna did not substitute the heptagonal house for the phoenix because he had no way to deal with a Greek fabulous bird or to find some kind of equivalent in his own culture. We begin to suspect that the substitution may be deliberate and, therefore, philosophically significant.

Confirmation that Ibn Sînâ's oriental disciples found the "heptagonal house" puzzling and knew about the 'anqa' as a possible candidate for a type of universal is given in a gloss to the first edition of Ibn Sînâs Metaphysics, the I885 Tehran lithograph, as indicated by Fr. Anawati in his notes to the French translation of Ibn Sînâ's text. ${ }^{\text {I9 }}$ Anawati in his

\footnotetext{
${ }^{16}$ Entry “"Ankâ"” in Encyclopaedia of Islam, $2^{\text {nd }}$. ed, p. 509. This may explain why according to Lane 'anqâ' mughrib may also mean a calamity or disaster.

${ }^{17}$ Pellat, 509.

${ }^{18}$ Avicenne (2006), Réfutation de l'astrologie, ed. Michot, Arabic, 6, ll. 3-I I; French, 58-59. On the importance of estimation to explain fictitious beings, see Black (I993), 227-32.

${ }^{19}$ Avicenne, La métaphysique du Shifầ, Livres I à V, transl. G. C. Anawati, 363-64. Mullâ Sadrâ al-Shîrâzî (ca. I572-I640) easily refers to the 'anâq', see Bonmariage (2007), 20, n. 2; 207, and I93, in particular n. 5.
} 
introduction indicates that he will provide notes only when the text is difficult. As explanation for the listing of the three kinds of universals, he offers a gloss by a certain Mulla Sulayman:

There are six kinds of universals: I. The universal, which includes only one individual and excludes any other, God; 2. The universal that includes no particular and excludes that any exist, for instance, any being associated to God; 3 . The universal that in principle does not include any particular but could exist, such as the griffon [al-'anqa']; 4. The universal that includes one particular, but could include more, for example, the sun; 5. The universal that includes an infinite number of individuals, such as the human souls for the philosophers; and 6. The universal that includes a finite number of individuals, such as the seven planets."

Sulayman then further explains 3, i.e., the universal that in principle does not include any particular but could exist, such as the 'anqâ', as a

Common notion according to the mind: this accepts that several particulars instantiating this universal could exist outside the mind, for instance, the heptagonal house. One can even say that it is not necessary that there even exist one particular in concrete existence, for instance the griffon (al-'anqa')."20

Notice that originally the 'anqâ' was first listed and that the heptagonal house comes as a secondary explanation. Sulayman considers the heptagonal house as something of which several instantiations could exist outside of the mind, whereas in the case of the 'anqâ' none does.

Further, if Avicenna had substituted the heptagonal house for the phoenix to replace a Greek fabulous animal with something as fabulous but known to his contemporaries, then we would need to assume, as

${ }^{20}$ Avicenne, La métaphysique du Shifâ', Livres I à V, transl. G. C. Anawati, note 195,5, pp. 363-64.

Tópicos 42 (2012) 
Hasnawi did in a discussion long ago, that the heptagonal house is mythical because regular heptagons cannot be constructed. This, as Hasnawi himself grants, creates problems because Jan P. Hogendijk in a I984 article established that no less than I 2 correct constructions of the regular heptagon were known or discovered by specialists in geometry in Islamic lands and five of them date from the late $\mathrm{IO}^{\text {th }}$ century. ${ }^{2 \mathrm{I}}$ We know that Ibn Sînâ was much interested in geometry as I. In his autobiography he claims to have worked out by himself the whole of Euclid's Elements, and 2. In his Shifâ' he provides a section on geometry. Therefore, he must have been aware that it was possible to construct a regular heptagon.

One interpreter, Jules Janssens claims that the heptagonal house is not fictitious and refers to a particular, which is possible but unrealized. ${ }^{22}$ As for Ibn Sînâ's Latin readers, they too may have rejected the heptagonal house as an example of a mythical being, since they knew how to construct regular heptagons, as the church of Rieux Minervois in the Aude Department in France testifies. It is a twelfth-century church, circular on the outside, but with an internal heptagonal plan and a cupola crowned by a heptagonal tower. Therefore, contrary to what de Libera assumes, the Latins were very far from having no idea of a heptagonal house ${ }^{23}$ and so some may have returned to the phoenix, precisely because they knew that a heptagonal building was not mythical and that there could be several instantiations of it.

de Libera offers the hypothesis that Avicenna introduced the heptagonal house to show how in a certain measure an artifact may be considered as a universal, even though it is not a "natural kind." 24 Whether one should follow Aristotle in assuming that artifacts are not really substances and, therefore, not really universals, was already discussed by Alexander of Aphrodisias and recently considered once again by Katayama. ${ }^{25}$ Avicenna does not discuss the issue in the Metaphysics of the Shifâ', but in

\footnotetext{
${ }^{2 \mathrm{I}}$ Hogendijk (I984), I97-330.

${ }^{22}$ Janssens (2006), 59.

${ }^{23}$ de Libera (I999), 5I2.

${ }^{24}$ Id., p. 5 I3.

${ }^{25}$ Katayama (I999).
} 
Book VI, ch. 2, the famous chapter that carefully distinguishes physical from metaphysical causes, i.e., accidental causes preceding their effects in existence from essential causes simultaneous with their effects, while speaking of essential causes, he does not differentiate between natural kinds, illustrated by the human being, artifacts, exemplified by the house, and the four elements, the forms of all of which are given by the famous "dator formarum", i.e., the Agent Intellect. We can conclude, then, that the point of the heptagonal house does not seem to be that it is an artifact. Besides, if the point were simply to introduce artifacts, why specify that the house be heptagonal and not simply speak as in VI, 2 of a house, without further qualification?

The conclusion of this preliminary inquiry is that the "heptagonal house" is substituted for the phoenix neither to illustrate a point dealing with a mythical being, be it a "natural" kind or an artifact, nor to illustrate the case of artifacts or man-made objects in general.

\section{Why Ibn Sînâ Could Not Use the Phoenix or Some Other Fabulous Animal}

Before proceeding further we need to consider first why the phoenix was introduced by Porphyry. Porphyry wished to present less common types of universals of which there is only one instance. In the case of the sun the only instance is eternal. The phoenix interested Porphyry and Simplicius after him because the legend assumes not only that the phoenix uses a very unusual mode of reproduction in dying on a pyre of which it itself fans the flames in order to be born again from its own ashes, but also claims that at every moment in time there is only a single phoenix for the whole world - and by the way this single phoenix is often considered to be living in Arabia - and so the single instance is not eternal but exists by succession in time in contrast to the case of the celestial bodies, such as the sun, which are eternal. Porphyry in his questions and answers On Aristotle's Categories puts it very clearly: 
Q. You also gave the species as predicated of several enumerable things. Does this hold in general?

A. No, only for the most part. The bird species phoenix is not said to belong to several things differing in number if indeed only one phoenix ever comes to be. If it is said of several things, they differ by succession (diadokhê), not in number. ${ }^{26}$

The mythical aspect of the phoenix did not interest the Greek commentators but rather its ability to be an apt example of a universal with a single instance by succession. So for Porphyry and for Simplicius, who follows suit, the phoenix as well as the sun illustrates the case of a universal with a single instantiation in contrast to the standard case of a universal with multiple instantiations. Avicenna seems to follow the same line of thought as his second and third kinds deal with universals with less than two instances, i.e., only one, eternal or not, or even none as in the case of the heptagonal house.

That Ibn Sînâ would be concerned by the issue of universals with only one instantiation or even none at all, as long as their conception is not opposed to multiplicity, does not surprise anyone who knows the two definitions of logical universals given by his eminent predecessor, alFârâbî, who follows the Arabic text of Aristotle's De interpretatione, 7, I7 a 39: "By the term "universal" I mean that which is of such nature as to be predicated of more than one" 27 and repeats this definition nearly word for word in his Commentary on this passage. ${ }^{28} \mathrm{He}$ also writes in his

\footnotetext{
${ }^{26}$ Porphyry On Aristotle's Categories, 82, 33-37, transl. Strange, 68. Greek text in Porphyre, Commentaire aux Catégories d'Aristote, ed. \& transl. R. Bodéüs, 206-08. For Simplicius, see de Libera (I999), 5I I. For both Porphyry's Commentary on the Categories and that of Simplicius, see D'Ancona (2008), I63 for Porphyry and I64 for Simplicius.

${ }^{27}$ Alon (2002), 4IO. The Greek had "of a number of things" but the Arabic specifies that it is more than one.

${ }^{28}$ [al-Fârâbî] (I960), 60, 11. 22-23.
} 
Eisagoge that "the universal is such that two or more resemble it... Further, the universal is such that it can be predicated of more than one." 29 In metaphysics and in logic Ibn Sînâ wishes to emphasize and illustrate against Aristotle and al-Fârâbî's well-known definitions that there can be logical universals that have only a single instantiation or even none at all.

As the point of the example of the phoenix was not the use of a fabulous animal but rather the giving of an example of a universal with a single instantiation or even none at all, it becomes clear that Ibn Sînâ may not have felt any particular inclination to substitute the Arabic 'anqâ' for the phoenix, particularly if the 'anqâ' is not necessarily conceived as being a species with a single instance at every point in time. Besides, if, as Pellat claims, one version of the legend makes clear that this bird is an extinct species, annihilated by a pre-Islamic prophet, then this would not have been at all palatable to Ibn Sînâ, who is convinced of the eternity of the species and even curiously claims in the Shifâ's Metaphysics, X, 4, that "[by marriage] is achieved the continuity of the species, the permanence of which is proof of the existence of God." 30

These reasons could already explain why Ibn Sînâ would not be enthusiastic about adopting the 'anqâ', but a philosophical difficulty grounded in the mythical aspect of the 'anqâ' compelled him to reject it. In the Shifâ' text the "meaning" of the heptagonal house was used to illustrate a universal that could be said of many but did not require that it be instantiated in more than one concrete being or in any at all. This formulation does not seem to exclude the 'anqâ' simply because there is no instance of it. The philosophical reason becomes clear in the text of the Ishârât:

${ }^{29}$ Arabic and transl. Alon (2002), 748.

${ }^{30}$ Avicenna, ed. Marmura, 372; this sentence is preceded by the following: "The first of the legislator's acts must pertain to marriage resulting in issue. $\mathrm{He}$ must call and urge [people] to it." The Latin is somewhat different: "Deinde quod primum debet instituere in civitate coniugum est, quod inducit generationem, et ut faciat illud nimis concupisci; per ipsam enim remanet species, cuius permanentia signum est divinae clementiae."

Tópicos 42 (2012) 
[The universal] is that the very conception of its meaning does not prevent it to receive commonality. If it is so prevented, then it is prevented by a cause external to its intelligible content. I. Some of them are common in actuality, for instance the human being; 2 . Some are common in potency and possibility, such as the sphere enclosing the pentagonal sides of the regular dodecahedron; and 3. Some are neither common in actuality nor in potency or possibility because of a cause outside the intelligible content itself, such as the sun for someone who does not allow for the existence of another sun. ${ }^{3 \mathrm{I}}$

First, between the Shifâ' and the Ishârât, the formulation of the definition of a universal has changed. In the Shifâ' the logical universal is "that whose very conception does not prevent its being said of many." The Ishârât shifts the emphasis to the commonality of the meaning of any universal, which can only be prevented by a cause external to it, and this leads to the introduction not only of actuality and potency but also of possibility, an important modal concept for Ibn Sînâ.

${ }^{31}$ Ibn Sînâ, Al Ishârât wa-t-Tanbîhât, ed. Donyâ, part I, I49, my translation. This edition comes with comments by al-Tûsî (I2OI-I274), who too claims that there are six kinds of universals: I. Those with an infinite number of multiple instantiations, for example, the human being; 2 . Those with a finite number of multiple instantiations, for example, the stars; 3 . Those with only one instantiation, but which could exist in many, such as the sun for those who allow for the existence of another one similar to it; 4 . Those with only one instantiation and that could not exist in many due to a cause different from their intelligible content, God; 5. Those which do not exist at all, but which could exist in many, such as the sphere in which the regular dodecahedron is inscribed; 6. Those which could not exist at all due to a cause different from their intelligible content, such as a being associated with God (p. I50). Al-Tûsî does not refer to the 'anqâ' and his classification in six kinds does not fully fit with that of the gloss on the metaphysics of the Shifâ' by Mulla Sulayman. He also understands the sphere in which a regular dodecahedron is inscribed as something that does not exist at all, but which could exist in many. The vocabulary of this formulation is less philosophically precise than that used by Ibn Sînâ. 
The commonality of universals - i.e., their ability to be shared by multiple instantiations - is now characterized by whether concrete instances exist in actuality, the first kind illustrated by the human being, or in potency and possibility, the second kind illustrated this time by the sphere in which one has inscribed a dodecahedron, or even in non - actuality, non - potency and non - possibility, but because of an external cause, the third kind, that of the sun. In itself a second sun is possible but this possibility is prevented by an external cause.

This discloses to us the real problem with the 'anqâ' or phoenix: this being is impossible in itself. As we have seen Ibn Sînâ points to this impossibility in his Refutation of Astrology, but he makes it abundantly clear in his Letter on the Disappearance of the Vain Intelligible Forms after Death also known as The Letter on the Soul. ${ }^{32}$ In this brief text Ibn Sinâ refers at least four times to the 'anqâ' as an impossible form or as something impossible (muhâl). ${ }^{33}$

This letter answers a question about what happens after death to forms of unreal things that had been present in a human being. It takes as its paradigmatic example the 'anqâ':

Every form which exists in the soul in such a way that it is possible for the intellect to admit in it commonality is universal and intelligible. Now among the impossible forms, there are some which have this characteristic, for example, the belief that the 'Anqâ' Mughrib exists in concrete singulars. Whoever admits its existence in concrete singulars also admits that it can be more than one individual. $\mathrm{He}$, therefore, believes something universal and this thing is intelligible. ${ }^{34}$

So a being contrary to the real is impossible in itself, but, if conceivable as instantiated in more than one individual, it is intelligible and

${ }^{32}$ Arabic text and French Michot (1987), I52-66. English translation Michot (I985), 94-IO3.

${ }^{33}$ Arabic text, I55, 1. II; I56, 11. 2I \& 22; I57, 1. 28.

${ }^{34}$ Michot's translation with slight modifications, 98. 
universal and its conception takes its origin in the imagination as we saw in the Refutation of Astrology. The Letter on the Soul tells us that:

When the imaginative faculty imagines some form, whether impossible or not impossible, the intellect accomplishes its specific action in it and makes it become intelligible. $^{35}$

Curiously and not very clearly the text, on the one hand, argues that such forms contrary to the real are not in any agent intellect because if they were, they would be instantiated, but, on the other hand, claims that such forms flow from these agent intellects. This seems contradictory but the contradiction can be resolved, if, following Jon McGinnis, we consider that what the agent intellect grants is not the specific content of these forms but rather simply the accident conferring universality to some conception already present, but as a particular, in the imagination. ${ }^{36}$ In some loosely written passages as is this one, Ibn Sînâ does not distinguish the intelligible content from the accidents of universality or particularity, linked to his famous doctrine of the indifference of the quiddity. As Deborah Black also speculates, I think that forms contrary to the real are impossible and, therefore, I. are not present in the agent intellects, and 2. cannot be instantiated, because Ibn Sinâ accepts, as the Neoplatonists apparently did, some form of the principle of plenitude that requires that possibles be realized either at every point in time or at least at some moment in time. ${ }^{37}$

In The Letter on the Soul Avicenna tells us:

It is not possible, we say, for these forms to exist in the permanent and everlasting things nor in the active intellects. The active intellects apprehend things in so far as they are concomitants of their essences.... But everything

\footnotetext{
${ }^{35}$ Michot's translation, 99.

${ }^{36} \mathrm{McGinnis} \mathrm{(2006),} \mathrm{I69-83.}$

${ }^{37}$ Black (I997), 429-3I.
} 
that is concomitant of something existing in actuality is inevitably existing in actuality. If something impossible was concomitant of the active intellects, it would thus necessarily exist in actuality. As the consequence is impossible, it remains that nothing impossible is concomitant of the active intellects and that they do not apprehend it, since we have said that they apprehend their concomitants. ${ }^{38}$

The concomitants of the active intellects seem to be the universals they are understanding and such universals concern only eternal beings, for instances the celestial bodies, which each are the single member of their own species, and natural kinds, instantiated through succession in time, as required by the eternity of species and the doctrine that God knows only universals. Phoenixes and other fabulous birds, if they were to exist, would be natural kinds and, therefore, eternally instantiated. As they are not so instantiated at all, they must be impossible and so they are not apprehended by the intelligences or God. Therefore, I would qualify Allan Bäck's claim that "Avicenna does not hold the strong principle of plenitude, sc., that whatever is possible must exist in re at some time," 39 which is based on a study of logical texts that does not include The Letter on the Soul. Avicenna, it seems to me, holds a very strong principle of plenitude for natural kinds as they must be instantiated not only at some time but rather at every point in time, but may not hold any principle of plenitude for artifacts. If this is the case, it may also be true that God knows only universals of natural kinds and not of artifacts. If artifacts are possible in themselves, their universals may at some stage be instantiated or remain for ever uninstantiated, though imagined at some point in time by some human being, whereas the 'anqâ' as member of a natural species must be instantiated at every point in time. ${ }^{40}$

${ }^{38}$ Michot's translation with some modification, Michot (I985), 99; Arabic text, Michot (I987), I56, 11. I7-2I.

${ }^{39}$ Bäck (I992), 233 \& 219.

${ }^{40} \mathrm{On}$ God's knowledge of universals and of some particulars in a universal way in Avicenna, see Marmura (I962), 7I-95. 
The impossibility of the 'anqâ' or any other fabulous animal explains why Avicenna did not wish to use it to illustrate universals of things possible in themselves but with only one instantiation or even none at all. Latin readers, who neither held any principle of plenitude nor accepted the eternity of the world and species, could safely return to the phoenix.

But in what concerns Avicenna, a new question arises: why did Avicenna not list a fourth kind of logical universal, though a very parasitic one, that of impossible but conceivable beings since in The Letter on the Soul he defends the view that the 'anqâ' is both intelligible and universal, though impossible in itself? Once again a rather unclear passage of this Letter gives an answer. Forms contrary to the real dissolve after death because "evil only proceeds from the Creator when indispensable. These forms that are opposed to the real were only flowing from Him as necessitated by the imagination" and so after death such forms "necessarily no longer flow from Him, whereas the real forms carry on doing so since it is good." $4 \mathrm{I}$ Why I. such forms are not simply vain but evil and 2. how the imagination necessitates their flowing from God remains unexplained. One can only speculate that since for Avicenna one of the greatest evils is ignorance, they are evil since they give a false certitude to those who believe that the 'anqâ' is really instantiated. ${ }^{42}$ Avicenna does not wish to waste his time on "false" universals, except maybe in a footnote so to speak or when someone raises the issue as in the Letter on the soul. Besides, in the Metaphysics of the Shifâ' the presentation of the kinds of universals follows a moderate realist stance on the ontological status of the universals in relations to concrete instances, offered in the Eisagoge, I, I2.43 In the Metaphysics the consideration of the kinds of universals serves to introduce the famous doctrine of the indifference of the quiddity to actuality and potency, universality and particularity. As a

\footnotetext{
${ }^{41}$ Michot's transl. with some modification, Michot (I985), IOO; Arabic, Michot (I987), I58, 11. 45-49.

${ }^{42}$ On Avicenna's conception of evil, see his Metaphysics of the Shifâ', Bk IX, ch. 6. On this also see Inati (I984), I70-86 and (2000) and Steel (2002), I7I-96.

${ }^{43}$ For a translation with comments of this chapter of Ibn Sînâ's Eisagoge, see Marmura, (I979), 33-59 and (I992), 6I-70.
} 
quiddity can be neutrally considered, so to speak, but always exists either in the concrete or in the imagination or the mind, and mental existence is very important for Ibn Sinâ, the 'anqâ' can inhabit the imagination but becomes an evil if it is also assumed to exist in the concrete. ${ }^{44}$

\section{III.Why did Ibn Sînâ Use the Heptagonal House?}

I have argued earlier that the second kind of universal refers to universals that have only one instantiation or none at all in contrast to the first kind, which has multiple instantiations. Though Olga Lizzini in a note refers to de Libera's interpretation of the heptagonal house as needed to speak of artifacts in general, in her introduction to the chapter she explains this kind of universal as "that which could be said of many, even if in fact these many do not exist. In this case the plurality of individuals is only in potency and, as in the case of the heptagonal house, there may not be even a single individual to correspond to the intention." 45 Yet, she does not explain the choice of this particular example and does not highlight as much as I do the contrast between universals with multiple concrete instantiations and those with a single instantiation or even none at all. So why the specific illustration of the heptagonal house?

To my knowledge it is only in the Metaphysics of the Shifâ' that Avicenna does offer the heptagonal house as an example of a universal whose meaning could be said of a single instantiation or even of none at all. True universals of this type cannot be meanings of natural kinds, since these must always be instantiated. Therefore, Avicenna had to illustrate them with some artifact, but not just any artifact would suffice, as most of the usual artifacts have many instantiations at many points in time. Avicenna, therefore, needed to find an artifact that was possible in itself but so difficult to realize and probably of so little practical utility, that either no instances would exist or only one at the utmost. He was certainly aware that new tools and techniques had been invented and, therefore,

\footnotetext{
${ }^{44}$ On the importance of mental existence for Avicenna, see Black (I999), 4579.

${ }^{45}$ Avicenna, Metafisica, ed. Lizzini \& Porro, n. 3, p. I I 43 and p. 427.
}

Tópicos 42 (20I2) 
had not always been instantiated, but tools and techniques are useful and so once known get multiplied. He had also to find something that was not only possible in itself, but whose instantiation was not prevented by some external cause, as was the case for the sun. All these requirements rendered the choice of an example difficult.

How could one ensure that something whose concrete instantiations had never been observed was really possible in itself and could be demonstrated to be so? Geometry offered solutions as things could be proven to be geometrically possible, and, therefore, in principle able to be instantiated, even if such things at the time of the discovery of their geometric properties could not be constructed because of technical difficulties, that could only be overcome at some later stage. If Ibn Sînâ was aware, as I have argued he is, that geometers could construct heptagons, he was also aware that now there were multiple drawings of regular heptagons and such drawings though they fit the requirement of being demonstrably possible did not fit the requirement of having only one instantiation or even none at all. He needed, therefore, to think of some heptagonal object that could be produced but that no one, except an eccentric, would produce as it would have no utility. What would be the point of producing a heptagonal house? The heptagonal shape would not have a practical purpose and not being easy to realize such a house would be probably more expensive than those of usual shapes. The heptagonal house fitted all the criteria to illustrate something that could demonstrably exist but had little chance of being instantiated and so could remain for ever a mere possibility or be only rarely realized. As far as I can understand, people are still puzzling why the church in Rieux has a heptagonal shape, said to be unique. One hypothesis is that seven, a sacred number, is somehow linked to Our Lady and a heptagonal shape would be in her honor, but, of course Marian symbolism is alien to Ibn Sînâ.

If the Shifâ's heptagonal house nicely fits the requirements to be possible in itself, difficult to realize, and without practical usefulness, one may then wonder why in the Ishârât Avicenna replaced it with a sphere in which a regular dodecahedron is inscribed. First, just as the heptagonal house, this sphere is grounded in geometry. The theorem that proves that 
in any sphere one can inscribe five types of regular solids, among them the dodecahedron, was well known. Hence such a sphere too is possible but it seems more difficult to construct than a heptagonal house and of still lesser utility. Even a heptagonal house is a house and can fulfill the usual purpose of any house or building, but such a sphere with its inner dodecahedron seems a fruitless enterprise as anyone can understand the theorem without looking at such a sphere or even at a regular dodecahedron. Maybe at this later stage of his life Avicenna had become more aware that heptagonal houses were more likely to be built than he had originally suspected and so was looking for something rarer or he simply did not care much about which specific geometric example to offer as long as it was unlikely to be instantiated.

\section{Conclusion}

Examining various texts of Ibn Sînâ and taking into account information from the history of science, from architecture, and from legends, as well as from texts in various languages, helped me to dig deeper in the philosophical issue of a kind of universals in Ibn Sînâ.

\section{Bibliography}

Ibn Sînâ (I960), Al-Shifấ, Al-Ilâhiyyât (I) (La métaphysique), ed. G.C. Anawati \& Sa'id Zayed, with an intro. by Ibrahim Madkour, Cairo, Organisation Générale des Imprimeries Gouvernementales.

Ibn Sînâ (I970), Al-Shifâ', La logique, III De l'interprétation (alibara), ed. M. el-Khodeiri, Preface by I. Madkour, Cairo, Dar el-Katib al-'arabi.

Ibn Sînâ (I983), Al-Ishârât wa-t-tanbîhât, part I, ed. S. Donyâ, Cairo, Dâr al-ma'âref.

Ibn Sînâ (I985), Najât, ed. D. Pazhuh, Tehran, Dâneshgah Tehran.

Avicenna (2009), The Physics of the Healing, Books III \& IV, A parallel English-Arabic text transl. introduced, and annotated by J. McGin- 
nis (Islamic Translation Series), Provo, Utah, Brigham Young University Press.

Avicenna (2003), Metafisica, con testo arabo e latino, ed. O. Lizzini \& P. Porro (Il pensiero occidentale), Milan, Bompiani.

Avicenna (2005), The Metaphysics of The Healing, A parallel English-Arabic text transl., introduced, and annotated by M. E. Marmura (Islamic Translation Series),Provo, Utah, Brigham Young University Press.

Avicenna (I985), "Avicenna's 'Letter on the Disappearance of the Vain Intelligible Forms after Death,"'ed. J. Michot, in Bulletin de Philosophie médiévale, 27, 94-I03.

Avicenna Latinus (1980), Liber de philosophia prima sive scientia divina, $V$-X, ed. S. Van Riet, with an intro. by G. Verbeke, Louvain, Peeters \& Leiden, E.J. Brill.

Avicenne (1986), Le livre de science, I: Logique, Métaphysique, transl. M. Achena \& H. Massé (Traductions de textes persans), Paris, Les Belles Lettres/UNESCO [reprint of I955].

Avicenne (1987), “'L'épître sur la disparition des formes intelligibles vaines après la mort' d'Avicenne," ed. and transl. J. Michot in Bulletin de Philosophie médiévale, 29, I 52-67.

Avicenne (2006), Réfutation de l'astrologie, ed., translation, intro., and notes Y. Michot (Sagesses musulmanes, 5), Beirut, Albouraq.

Avicenne (I978), La métaphysique du Shifấ, Livres I à V, transl. with intro. and notes by G. C. Anawati (Etudes musulmanes XXI), Paris, Vrin.

[al-Fârâbî] (I960), Alfarabi's Commentary on Aristotle's Peri Hermeneias (De interpretatione), Arabic ed. with an intro W. Kutsch \& S. Marrow, Beirut, Imprimerie Catholique.

Porphyry (I992), On Aristotle's Categories, transl. S. K. Strange, Ithaca, NY, Cornell University Press.

Porphyre (2008), Commentaire aux Catégories d'Aristote, critical ed., French transl., and notes R. Bodéüs (Bibliothèque des textes philosophiques), Paris, Vrin.

Alon I (2002), Al-Fârâbî’s Philosophical Lexicon, vol. I, Arabic Text, Vol. II, English Translation, no city, E.J.W. Gibb Memorial Trust. 
Bäck, A. (I987), "Avicenna on Existence," Journal of the History of Philosophy, 25, 35I-67.

Bäck, A. (I992), “Avicenna's Conception of the Modalities," Vivarium, 30, 2I 7-55.

Bertolacci, A. (2006), The Reception of Aristotle's Metaphysics in Avicenna's Kitâb al-Shifâ': A Milestone of Western Metaphysical Thought (Islamic Philosophy, Theology and Science, 63), Leiden, Brill.

Black, D.L. (I999), "Mental Existence in Thomas Aquinas and Avicenna," Mediaeval Studies, 6I, 45-79.

Black, D.L. (I 997), "Avicenna on the Ontological and Epistemic Status of Fictional Beings," Documenti e Studi, 8, 425-53.

Black, D. L. (I993), "Estimation (Wahm) in Avicenna: The Logical and Psychological Dimensions," Dialogue, 32, 227-32.

Bonmariage, E. C. (2007), Le réel et les réalités. Mullâ Sadrâ Shîrâzî et la structure de la réalité (Etudes musulmanes 4I), Paris, Vrin.

D’Ancona, C. (2008) entry "Aristotle and Aristotelianism," in Encyclopaedia Islamica, $3 \mathrm{r}$ ed., fasc. I, I53-69.

de Libera, A. (I996), La querelle des universaux. De Platon à la fin du Moyen Âge, Paris, Seuil.

de Libera, A. (I999), L'art des généralités. Théories de l'abstraction (Philosophie), Paris, Aubier.

Gutas, D. (I988), Avicenna and the Aristotelian Tradition: Introduction to Reading Avicenna's Philosophical Works (Islamic Philosophy and Theology, 4), Leiden, Brill.

Hogendijk, J.P. (I984), "Greek and Arabic Constructions of the Regular Heptagon," Archive for History of Exact Sciences, 30, I97-330.

Inati, S.C. (I984), "An Examination of Ibn Sînâ's Theodicy: Dissolving the problem of Evil," The New Scholasticism, 58, I70-86.

Inati, S.C. (2000), The Problem of Evil: Ibn Sînâ's Theodicy, Binghamton, N.Y., Global Publications.

Janssens, J. (2006), “Avicenne,” in Le vocabulaire des philosophes, Supplements I, vol. V, ed. P. Magnard, Paris, Ellipses, I3-64. 
Katayama, E.G. (I999), A ristotle on Artifacts: A Metaphysical Puzzle (SUNY Series in Ancient Greek Philosophy), Albany, State University of New York Press.

Kennedy-Day, K. (2003), Books of Definition in Islamic Philosophy: The Limits of Words, London, Routledge Curzon.

Marmura, M.E. (I962), "Some Aspects of Avicenna's Theory of God's Knowledge of Particulars," in his Probing in Islamic Philosophy: Studies in the Philosophies of Ibn Sina, al-Ghazali and other Major Muslim Thinkers, Binghamton, N.Y., Global Academic Publishing, 2005, 7 I95 (originally published in I962).

Marmura, M.E. (I979), "Avicenna's Chapter on the Universals in the Isagogue of his Shifâ,," in his Probing in Islamic Philosophy: Studies in the Philosophies of Ibn Sina, al-Ghazali and other Major Muslim Thinkers, Binghamton, N.Y., Global Academic Publishing, 2005, pp. 3359 (originally I979).

Marmura, M.E., (I992), "Quiddity and Universality in Avicenna," in his Probing in Islamic Philosophy: Studies in the Philosophies of Ibn Sina, al-Ghazali and other Major Muslim Thinkers, Binghamton, N.Y., Global Academic Publishing, 2005, pp. 6I-70 (originally I992).

McGinnis, J. (2006), "Making Abstraction Less Abstract: The Logical, Psychological, and Metaphysical Dimensions in Avicenna's Theory of Abstraction," Proceedings of the American Catholic Philosophical Association, 80, I69-83.

Pellat, Charles, 'Ankâ' in Encyclopaedia of Islam, ed. by H.A.R. Gibb et alii, $2^{\text {nd }}$. ed., vol. I (Ledien: Brill, I960), p. 509.

Steel, C. (2002), "Avicenna and Aquinas on Evil," in Avicenna and his Heritage, ed. J. Janssens \& D. De Smet (Ancient and Medieval Philosophy, 28), Louvain, Leuven University Press, I7I-96.

Zimmermann, F. W. (I98I), Al-Farabi's Commentary and Short Treatise on Aristotle's De intepretatione (The British Academy Classical and Medieval Logic Texts), London, Oxford University Press. 
